\title{
COPYRIGHT ACKNOWLEDGMENTS
}

The editors and publisher gratefully acknowledge permission from the following sources for selections published herein:

The Collected Papers of C. S. Peirce, volume VI, edited by Charles Hartshorne and Paul Weiss. Copyright (C) 1935 by the President and Fellows of Harvard College. Reprinted by permission of Harvard University Press.

"The Dilemma of Determinism" (1884), "The Stream of Consciousness" (1892), and "The Problem of Novelty" (1911) by William James. Published by Harvard University Press.

The Complete Works of Friedrich Nietzsche, volume 16, edited by Oscar Levy, translated by Anthony Ludovici (New York: Russell \& Russell, 1964). Reprinted by permission of Scribner, a Division of Simon \& Schuster.

Time and Free Will by Henri Bergson, translated by F. L. Pogson. Published by George Allen \& Unwin, 1910.

The Creative Mind by Henri Bergson, translated by Mabelle L. Andison. Copyright 1946 by the New Philosophical Library.

The Collected Works of John Dewey: The Later Works, volume 1 (1981), volume 5 (1984), volume 14 (1988). Copyright (C) 1981, 1984, 1988 by the Board of Trustees, Southern Illinois University.

Science and the Modern World by Alfred North Whitehead. Copyright 1925 by Macmillan Publishing Company and Cambridge University Press; copyright renewed (C) 1953 by Evelyn Whitehead. Reprinted by permission of Simon \& Schuster and Cambridge University Press. 
Process and Reality, Corrected Edition, by Alfred North Whitehead, edited by David Ray Griffin and Donald W. Sherbune. Copyright 1929 by Macmillan Publishing Company; copyright renewed (C) 1957 by Evelyn Whitehead. Copyright (C) 1978 by The Free Press. Reprinted by permission of Simon \& Schuster.

Adventures of Ideas by Alfred North Whitehead. Copyright 1933 by Macmillan Publishing Company and Cambridge University Press; copyright renewed (C) 1961 by Evelyn Whitehead. Reprinted by permission of Simon \& Schuster and Cambridge University Press.

“Objects and Subjects" by Alfred North Whitehead, Philosophical Review 41 (1932). Copyright 1932 by Cornell University. Reprinted by permission of the publisher.

The Philosophy of the Present by George Herbert Mead. Copyright 1925 by The University of Chicago Press.

Reality as a Social Process: Studies in Metaphysics and Religion by Charles Hartshorne. Copyright (C) 1953 by The Free Press; copyright renewed 1981 by Charles Hartshorne. Reprinted by permission of The Free Press, a Division of Simon \& Schuster.

The Logic of Perfection and Other Essays in Neoclassical Metaphysics by Charles Hartshorne. Copyright 1962 by Open Court Publishing Company, a division of Carus Publishing. 